\title{
Electrodialytic Recovery of Ammonium and Phosphate lons in Fertilizer Industry Wastewater by Using a Continuous-Flow Reactor
}

\author{
Desiana Nurul Hikmawati ${ }^{1}$, Arseto Yekti Bagastyo ${ }^{1 *}$, Idaa Warmadewanthi ${ }^{1}$ \\ 1 Department of Environmental Engineering, Faculty of Civil, Environmental, and Geo-Engineering Institut \\ Teknologi Sepuluh Nopember, Surabaya 60111, Indonesia \\ * Corresponding author's e-mail: bagastyo@enviro.its.ac.id
}

\begin{abstract}
The wastewater stream generated from fertilizer industries generally contains high concentrations of ammonium and phosphate ions. This stream offers an opportunity for the electrodialytic process to treat and recover these concentrated nutrients before releasing them to the environment. Therefore, this study aims at evaluating the performance of a continuous-flow electrodialysis reactor for ionic recovery of ammonium and phosphate. The results show that the $\mathrm{pH}$ and phosphate mass loading affected the overall performance of the reactor. Magnesium was added to the recovered ammonium and phosphate with the lowest concentration of impurity ions. The molar ratio of magnesium:ammonium:phosphate at 2.5:13:1 produced $57.3 \%$ of struvite (by mass) and $42.7 \%$ of other precipitate products, i.e., most likely fluorapatite and $\mathrm{MgF}_{2}$.
\end{abstract}

Keywords: electrodialysis, fertilizer wastewater, nutrient recovery, struvite

\section{INTRODUCTION}

The fertilizer industry generates a wastewater stream containing a high concentration of nutrients and a certain amount of calcium and fluoride. If the wastewater is discharged without proper treatment, it results in eutrophication and other problematic environments. Some common wastewater treatments applied in the fertilizer industry are biological and physicochemical processes targeting at the removal and/or recovery of ammonium and phosphate. In terms of ammonium and phosphate recovery to obtain struvite formation, other impurity ions contained in the wastewater need to be eliminated. Electrodialysis technology is used mainly for desalinating and concentrating wastewater (Wang et al., 2015). Electrodialysis is one of the wastewater treatment methods utilized to recover ammonium and phosphate ions in soluble form, whereas chemical precipitation is one of the physicochemical methods to recover ammonium and phosphate as struvite solid materials. Mondor et al. (2008) produced a concentrated nitrogen fertilizer (containing $13 \mathrm{~g} / \mathrm{L}$ of $\mathrm{NH}_{4}-\mathrm{N}$ ) from liquid swine manure using electrodialysis and reverse osmosis. Another method for phosphate recovery is electrodialysis or novel electrodialysis to improve the efficiency of phosphate recovery from a struvite reactor (Zhang et al., 2013).

Struvite is a phosphate fertilizer, containing a significant amount of nitrogen and magnesium, and it is an effective alternative source of rock phosphate to maintain the agricultural production system (Rahman et al., 2014). The deposition of struvite is influenced by several factors, such as $\mathrm{pH}$ and ion molar ratio. Some researchers stated different $\mathrm{pH}$ value of solubility for struvite formation, e.g., ranges from 8.0 to 10.6 (Momberg \& Oellermann, 1992). Another study stated that the optimum struvite precipitation occurred at magnesium:ammonium:phosphate molar ratio of 2.5:15:1 with $200 \mathrm{rpm}$ of stirring at $\mathrm{pH}$ 9, i.e., obtaining $33.5 \%$ and $92.5 \%$ removal of ammonium and phosphate, respectively (Warmadewanthi \& Liu, 2009).

The studies on electrodialysis and chemical precipitation for ammonium and phosphate recovery are becoming more attractive due to the 
potential formation of struvite as an added-value product. However, to the author's knowledge, there was a gap in determining the efficiency of integrating both methods for struvite formation. Therefore, this study aims at evaluating the efficiency of ammonium and phosphate recovery simultaneously with calcium and fluoride removal from the fertilizer industry wastewater using a continuous flow electrodialysis system. A twostage electrodialysis process was conducted by applying two equally-shaped reactors arranged in series. Following this, chemical precipitation was conducted by adding $\mathrm{MgCl}_{2}$ to the recovered ammonium and phosphate ions from electrodialysis processes at particular molar ratios. The evaluation of this integrated system was performed by using Phreeqc Interactive application tools to support the prediction of struvite formation from the obtained molar ratio in the electrodialysis effluents.

\section{MATERIAL AND METHODS}

\section{Fertilizer industry wastewater}

The wastewater was taken from the effluent of the equalization tank, which is the wastewater collection unit processes applied by the industry. The existing wastewater treatment is originally designed to eliminate the high concentrations of ammonium and phosphate as well as organic compounds. The characteristics of the wastewater used in this study are shown in Table 1.

\section{Electrodialysis reactor}

Two sets of reactors were configured in series to perform a continuous flow of two-stage electrodialysis system. Each electrodialysis reactor comprised three compartments, i.e., separated by AEM and CEM (Membranes International Inc., USA.), creating anode, cathode, and concentrate (central) compartments. This configuration allows the simultaneous removal of anions and cations. Each compartment has an internal dimension of $20 \times 10 \mathrm{~cm}^{2}$ and a thickness of 2 $\mathrm{cm}$ (i.e., an active volume of $400 \mathrm{~mL}$ ). Both reactors were also equipped with carbon anode and stainless steel cathode. The electrodes were connected to DC power supply (Dekko PS - 305Q) at a constant current of $0.75 \mathrm{~A}$ as already obtained from the previous study (Bagastyo et al., 2017). The wastewater was pumped through the first reactor to recover the ammonium and phosphate ions, and the effluent then flowed to the second reactor to recover the residual ions from the first reactor. Both the recovered ammonium and phosphate ions were accumulated in the central "concentrate" compartment, applying a batch recirculation system. The central compartment was filled by pure water (aquabidest) to receive ions that migrate through the membrane from anode and cathode compartments. The reactor configuration is shown in Figure 1.

\section{Chemical precipitation}

In this experiment, struvite precipitation was conducted by using a jar test method in rectangular reactors. The reactor made of acrylic had the dimensions of $10 \times 10 \times 14 \mathrm{~cm}^{3}$ with an effective capacity of $1 \mathrm{~L}$. Thus, the struvite chemical precipitation was performed using $1 \mathrm{~L}$ of the electrodialysis effluent obtained from the concentrate compartment.

Table 1. The wastewater characteristics

\begin{tabular}{|c|c|c|c|c|c|c|}
\hline No & $\begin{array}{c}\text { Mass range of } \\
\mathrm{PO}_{4}{ }^{3-}(\mathrm{g})\end{array}$ & $\begin{array}{c}\text { Conc. of } \mathrm{PO}_{4}{ }^{3-} \\
(\mathrm{mg} / \mathrm{L})\end{array}$ & $\begin{array}{c}\text { Conc. of } \mathrm{NH}_{4}{ }^{+} \\
(\mathrm{mg} / \mathrm{L})\end{array}$ & $\begin{array}{c}\text { Conc. of } F^{-} \\
(\mathrm{mg} / \mathrm{L})\end{array}$ & $\begin{array}{c}\text { Conc. of } \mathrm{Ca}^{2+} \\
(\mathrm{mg} / \mathrm{L})\end{array}$ & $\mathrm{pH}$ \\
\hline \multirow{4}{*}{1.} & \multirow{4}{*}{$51-80$} & 1.413 & 3.891 & 322 & 267 & 7.5 \\
\hline & & 1.775 & 3.891 & 449 & 444 & 8 \\
\hline & & 3.829 & 4.772 & 753 & 2.667 & 8.5 \\
\hline & & 3.520 & 5.821 & 139 & 333 & 9 \\
\hline \multirow{4}{*}{2.} & \multirow{4}{*}{$21-50$} & 3.095 & 3.897 & 899 & 2.667 & 7.5 \\
\hline & & 2.554 & 2.809 & 95 & 200 & 8 \\
\hline & & 712 & 3.984 & 365 & 267 & 8.5 \\
\hline & & 626 & 3.433 & 178 & 267 & 9 \\
\hline \multirow{4}{*}{3.} & \multirow{4}{*}{$10-20$} & 882 & 5.308 & 163 & 333 & 7.5 \\
\hline & & 1.924 & 4.308 & 871 & 4.667 & 8 \\
\hline & & 827 & 5.231 & 207 & 200 & 8.5 \\
\hline & & 692 & 5.141 & 176 & 267 & 9 \\
\hline
\end{tabular}




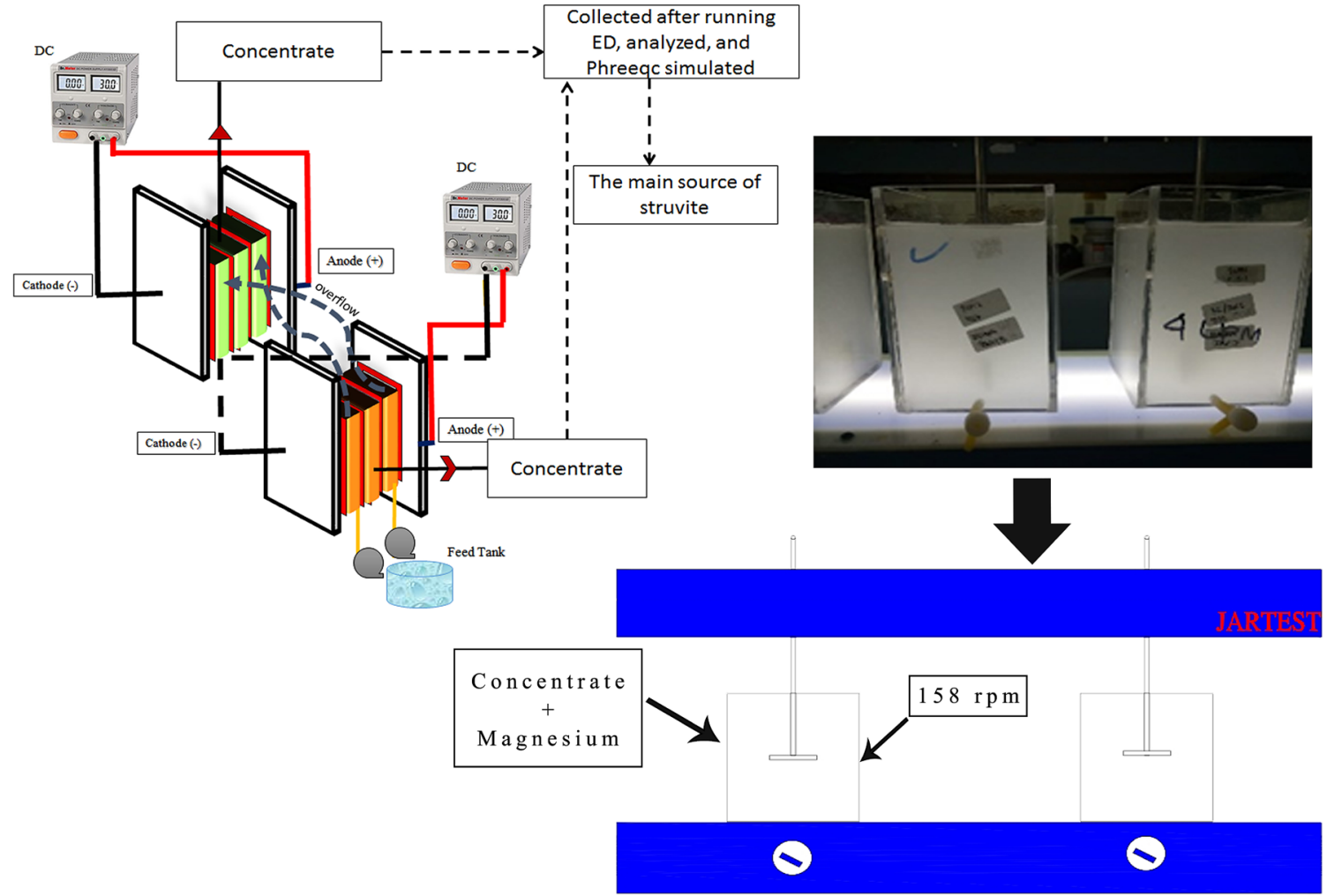

Figure 1. Schematic diagram of electrodialysis recovery and struvite precipitation

\section{Electrodialysis and chemical precipitation experiments}

The wastewater was pumped from the feed tank by a peristaltic pump at a flowrate of 0.1-0.4 $\mathrm{mL} / \mathrm{s}$, parallel to the anode and cathode compartments of Reactor 1 . The effluents of these two compartments were then continuously flowed to Reactor 2, i.e., the anode effluent of Reactor 1 flowed to the cathode of Reactor 2, and vice versa. This allows continuous recovery of ammonium and phosphate ions as well as removal of fluoride and calcium ions in both reactors. Up to 34-L of wastewater was electrodialysed for the operational time of 10 hours. Simultaneously, the separated central compartment at two reactors was filled by the recirculated 4-L pure water, namely the concentrate stream.

The wastewater was adjusted to $\mathrm{pH} 7.5,8$, 8.5 , and 9 to evaluate the migration efficiency of different ion speciation during electrodialysis. Three wastewater characteristics were taken into account in order to determine the load capacity of the reactor system. The wastewater was classified based on phosphate mass loading range of 10-20, 21-50, and 51-80 g. In addition, the wastewater was prepared by adjusting the flowrate based on the initial concentration of phosphate in the wastewater. Meanwhile, the $\mathrm{pH}$ was adjusted by adding a small amount of $\mathrm{NaOH} 3 \mathrm{M}$ or $\mathrm{HCl} 3 \mathrm{M}$ to the wastewater.

In regards to chemical precipitation, the concentrate stream produced during electrodialysis was then added by a specific amount of $\mathrm{MgCl}_{2}$ and $\mathrm{NaOH}$ to form solid struvite precipitates in a batch agitation system at $158 \mathrm{rpm}$ of mixing. The data of electrodialysis concentrate stream was processed by using Phreeqc interactive software to simulate and adjust the molar ratio of magnesium:ammonium:phosphate for struvite formation and other possible precipitates, such as fluorapatite, magnesium fluoride, and hydroxyapatite. The concentrations of $\mathrm{F}^{-}$and $\mathrm{Ca}^{2+}$ impurities were calculated as supporting data in the Phreeqc simulation.

\section{Sample analysis}

The samples were taken every 2 hours over 10 hours of electrodialysis process for further chemical analysis. Sampling was conducted on each compartment. The concentrations of $\mathrm{NH}_{4}^{+}$, $\mathrm{PO}_{4}^{3-}, \mathrm{Ca}^{2+}$ dan $\mathrm{F}^{-}$were measured during electrodialysis, whereas the concentrations of $\mathrm{NH}_{4}^{+}$ and $\mathrm{PO}_{4}^{3-}$ were measured during chemical precipitation experiment. The analytical methods 
performed were Nessler (for $\mathrm{NH}_{4}^{+}$), tin(II) chloride (for $\mathrm{PO}_{4}^{3-}$ ), and SPADNS (for $\mathrm{F}^{-}$) as well as titrimetric EDTA (for $\mathrm{Ca}^{2+}$ ) as standard analysis. The analyses of XRD and SEM-EDX were conducted to identify the precipitates produced during chemical precipitation and to physically compare the possible struvite formation, respectively.

\section{RESULTS AND DISCUSSION}

\section{Ammonium and phosphate recovery in the electrodialysis process}

The results of the phosphate and ammonium recovery process were obtained in the concentrate compartment at Reactor 1 and 2 . The results of the electrodialytic recovery of $\mathrm{NH}_{4}^{+}$and $\mathrm{PO}_{4}^{3-}$ ions in phosphate mass loading of $10-20 \mathrm{~g}$ at $\mathrm{pH} 7.5,8.0$, 8.5, and 9.0 are shown in Figure 2a-b. It can be seen that the ammonium and phosphate recovery at $\mathrm{pH} 7.5$ to 9.0 was gradually increased in both Reactor 1 and 2, i.e., approximately up to 0.3 mass recovery ratio of $\mathrm{NH}_{4}^{+}$and $\mathrm{PO}_{4}^{3-}$ ions from the initial mass after $0.31 \mathrm{Ah} / \mathrm{L}$. In this study, the applied current density and the average voltage was $5 \mathrm{~mA} / \mathrm{cm}^{2}$ and of $24 \mathrm{~V}$. The increase in the recovery of phosphate and ammonium recovery can be influenced by current density and voltage applied to the reactor. This is supported by Wang et al. (2013) who reported that the current density of $10 \mathrm{~mA} / \mathrm{cm}^{2}$ and voltage of $24 \mathrm{~V}$ showed a better electrodialytic recovery of phosphate. Similarly, Novalin et al. (2017) report that phosphate separation was significantly improved by the current density of $11.7 \mathrm{~mA} / \mathrm{cm}^{2}$. Mulder (1996) suggests that the current density is determined not only by the applied voltage and but also by the total resistance at the reactor. The use of multiple membranes could considerably increase internal resistance, thus requiring higher amount of

a)

Massa $10-20 \mathrm{pH} 7.5-8$

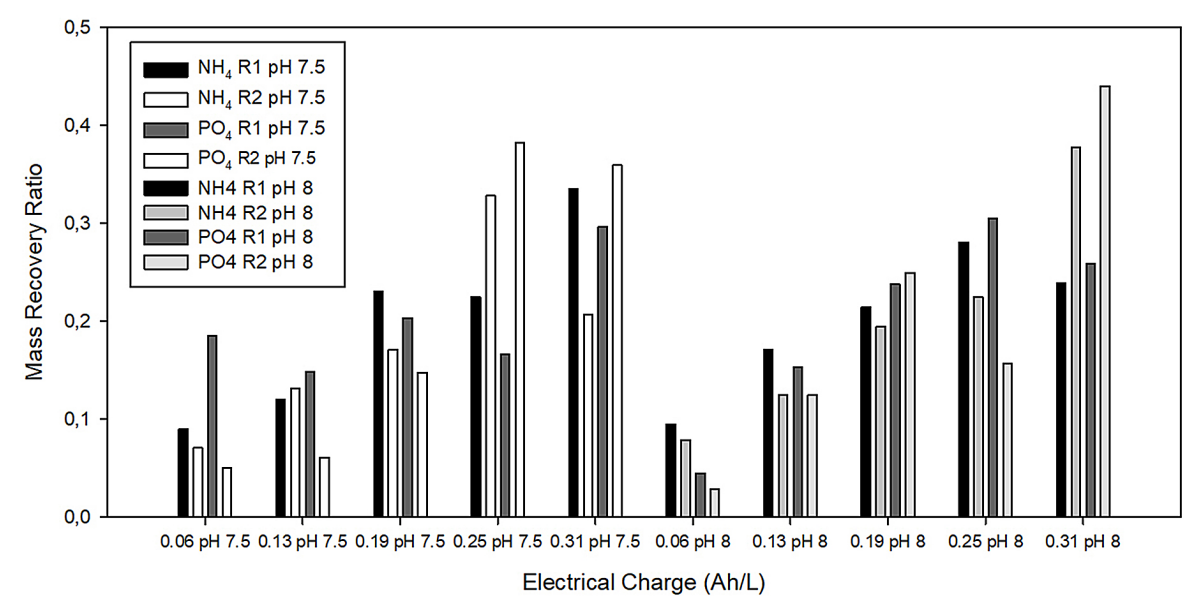

b)

Massa $10-20 \mathrm{pH} 8.5-9$

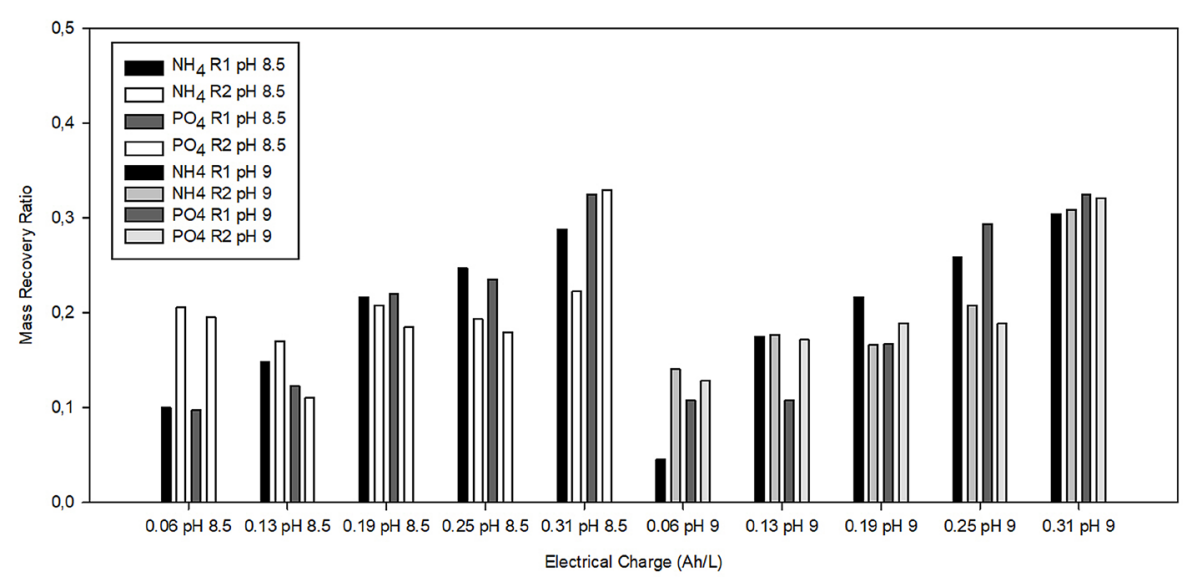

Figure 2. Electrodialytic recovery of $\mathrm{NH}_{4}^{+}$and $\mathrm{PO}_{4}^{3-}$ in the phosphate mass loading of 10-20 g at pH: (a) 7.5-8.0; (b) 8.5-9.0 
energy. The increase in current density leads to an increase in the number of ions transferred through the ionic exchange membranes.

Similarly, the recovery of $\mathrm{NH}_{4}^{+}$and $\mathrm{PO}_{4}{ }^{3-}$ was achieved in the phosphate mass loading of 21-50 $\mathrm{g}$ as shown in Figure 3. The recovery of $\mathrm{NH}_{4}^{+}$and $\mathrm{PO}_{4}^{3-}$ was clearly observed in Reactor 1 and 2, particularly at $\mathrm{pH} 7.5$ and $\mathrm{pH} 8.5$, although the trend was fluctuative. Nevertheless, the results show a considerable increase of $\mathrm{NH}_{4}{ }^{+}$and $\mathrm{PO}_{4}{ }^{3-}$ recovery along with the electrical charge, i.e., from around 0.1 mass recovery ratio at $0.06 \mathrm{Ah} / \mathrm{L}$ increased in the range of up to $0.35-0.4$ mass recovery ratio at $0.31 \mathrm{Ah} / \mathrm{L}$. Wang et al. (2013) state that the flow rate may affect the stability of phosphate concentration recovered. The study suggests that a lower flow rate, i.e., $10 \mathrm{~mL} / \mathrm{min}$ is required for a continuous setup applied in electrodialysis. The flow rate used in this present study amounted to 6-24 $\mathrm{mL} / \mathrm{min}$, which was applied depending on the initial concentration of phosphate mass loading. A higher flow rate applied to the electrodialysis system would lead to an increase in phosphate mass pumped into the reactor. This may indicate that the capacities of Reactor 1 and 2 are exceeded.

According to Karimi (2015), the total mass removal of divalent and monovalent ions was increased in the case of wastewater containing initial mass loading, because more ions would be ionized and electrodialysed by the given voltage at the same time. However, Ali et al. (2010) mention that the percentage of ionic removal was decreased at high concentrations of contaminants in the wastewater, i.e., between 500 and $3000 \mathrm{mg} / \mathrm{L}$. This could have occurred due to the fact that the removal was decreased at the high initial concentration of wastewater. Nevertheless, it can be expected that the removal of ionic in the wastewater would be balanced to the recovered ions in the concentrate stream.

a)

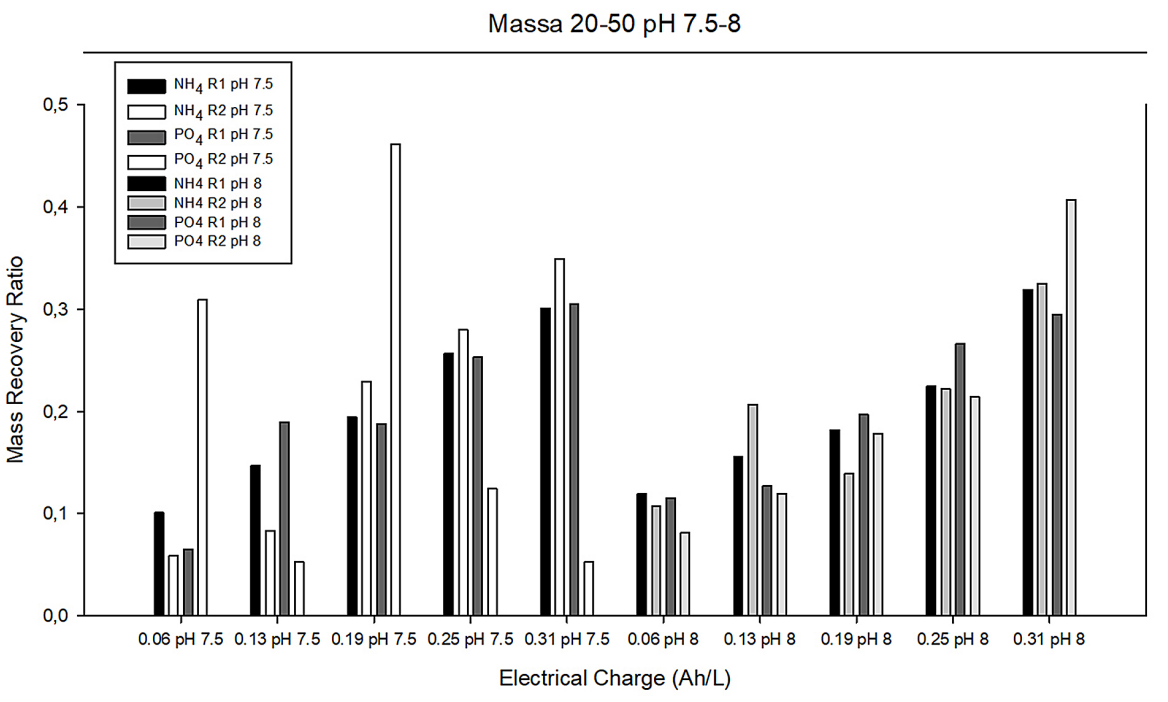

b)

Massa $20-50 \mathrm{pH}$ 8.5-9

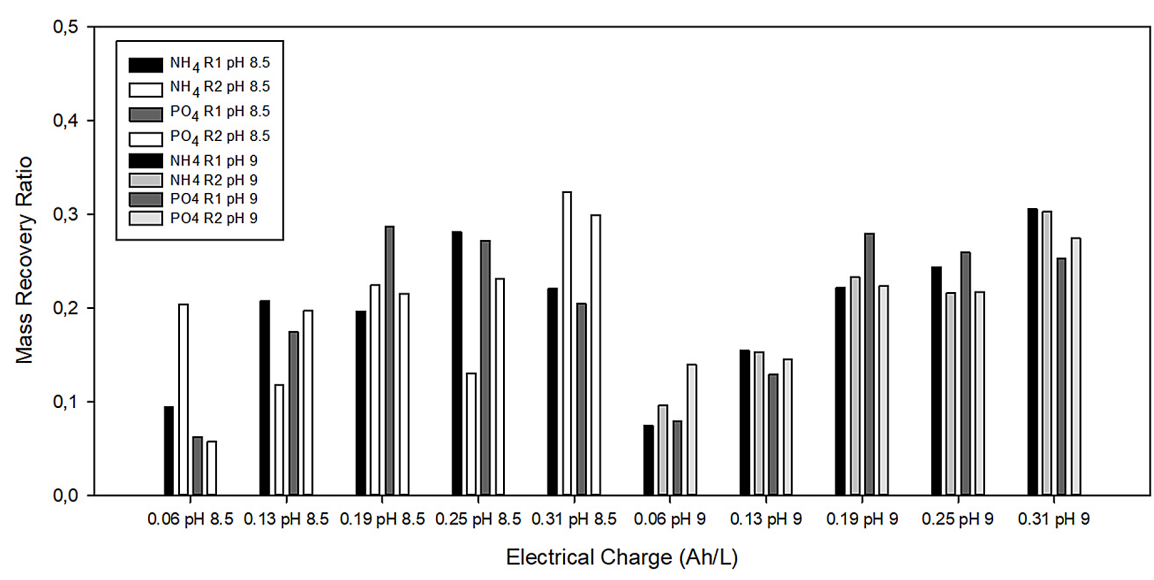

Figure 3. Electrodialytic recovery of $\mathrm{NH}_{4}^{+}$and $\mathrm{PO}_{4}^{3-}$ in phosphate mass loading of $21-50 \mathrm{~g}$ at $\mathrm{pH}$ : (a) $7.5-8.0$; (b) $8.5-9.0$ 
In general, Figure 4 presents the result of the recovery process that was almost identical to the phosphate mass loading of 51-80 g. At $\mathrm{pH} 7.5$ and 8.0, the recovery declined at 6 hours of operation (i.e., $0.19 \mathrm{Ah} / \mathrm{L}$ ). Then, the recovery increased until the final operational time (i.e., 0.31 $\mathrm{Ah} / \mathrm{L}$ ). This can possibly be observed due to the increased initial phosphate mass loading in the wastewater influent, similar to the case of phosphate mass loading of 21-50 g.

Overall, the average mass recovery of phosphate and ammonium at $\mathrm{pH}$ 7.5-9.0 achieved in all phosphate mass loading is presented in Table 2. At pH 7.5, it can be concluded that the recovery process with phosphate mass loading of up to $51-80 \mathrm{~g}$ can be performed efficiently in Reactor 1 and 2, i.e., 0.44-0.56 g phosphate was obtained in Reactor 1 and 0.37-1.31 g in Reactor 2 for every 2 hours. Under the same conditions, in the average of up to $2.99 \mathrm{~g}$ ammonium was recovered in Reactor 1, and up to $2.26 \mathrm{~g}$ on average in Reactor 2. Although electrodialysis process at pH 8 was not beneficial for ammonium and phosphate recovery, the process at $\mathrm{pH} 9$ was preferable for ammonium recovery. This could be due to the speciation of ammonium that is affected by the $\mathrm{pH}$ condition.

\section{Ion mobility of phosphate and ammonium}

The ion transfer in the electrodialysis is determined by the driving force occurred on each ionic compound in the solution. There was friction on each ionic compound when migrating in the solution and passing through the ion exchange membrane. The friction or resistance that must be overcome by the driving force to move the compound can be expressed as mobility (Strathmann, 2004). The result shows the positive effect for phosphate as well as total concentrate produced at $\mathrm{pH} 7.5$ and 9. The mobility of phosphate and fluoride depends on ionic speciation due to ionic

a)

Massa $50-80 \mathrm{pH} 7.5-8$
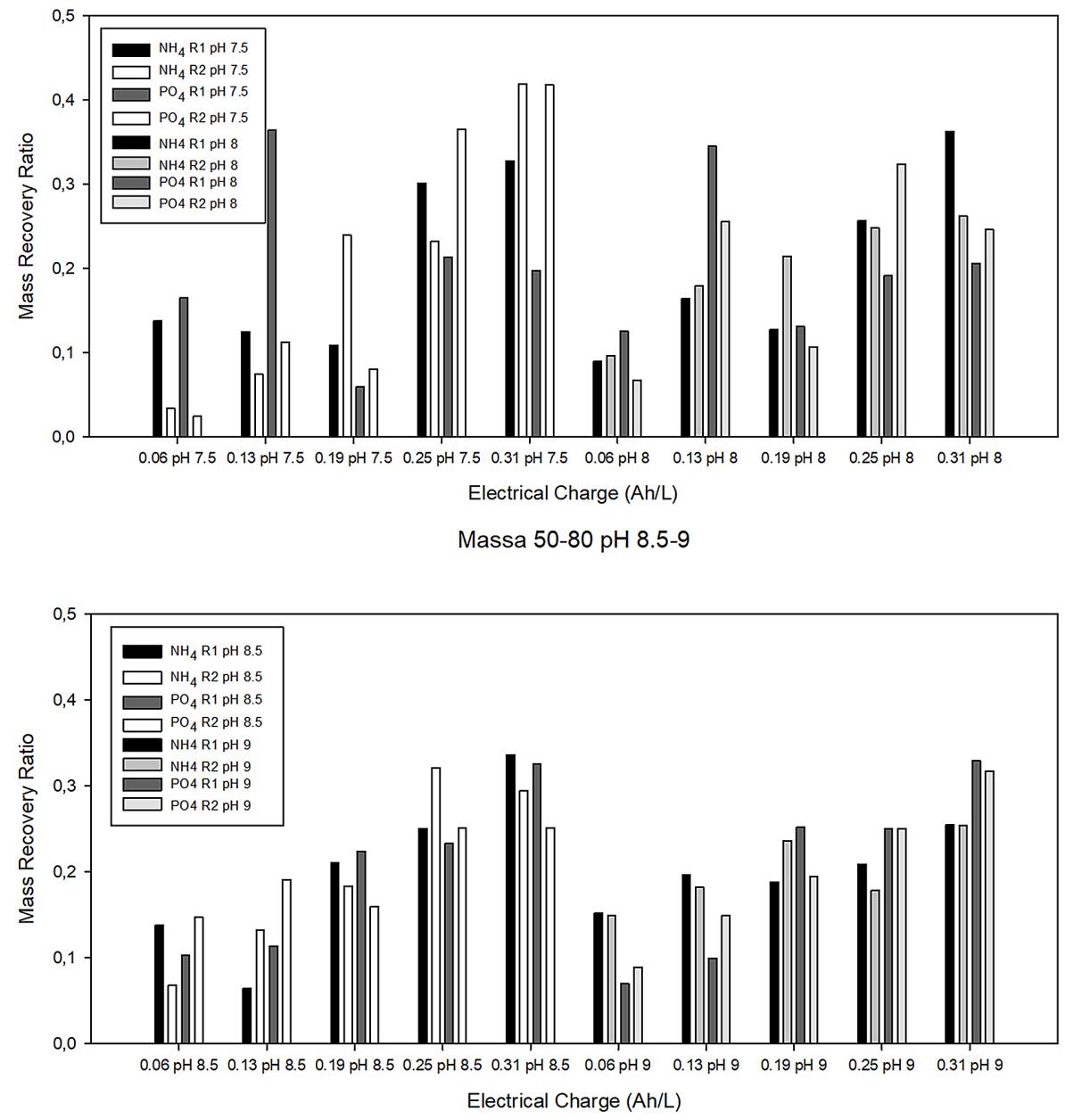

Figure 4. Electrodialytic recovery of $\mathrm{NH}_{4}^{+}$and $\mathrm{PO}_{4}^{3-}$ in phosphate mass loading of 51-80 $\mathrm{g}$ at $\mathrm{pH}$ : (a) 7.5-8.0; (b) 8.5-9.0 
Table 2. Average mass recovery

\begin{tabular}{|c|c|c|c|c|c|}
\hline Phosphate mass & Phosphate (g) & Ammonium (g) & Phosphate mass & Phosphate (g) & Ammonium (g) \\
\hline \multicolumn{3}{|c|}{$\mathrm{pH} 7.5$} & \multicolumn{3}{|c|}{$\mathrm{pH} 8.0$} \\
\hline $10-20 \mathrm{~g}$ & $0.44 \mathrm{R} 1$ and $0.55 \mathrm{R} 2$ & 2.99 R1 and 2.19 R2 & $10-20 \mathrm{~g}$ & $0.53 \mathrm{R} 1$ and $0.34 \mathrm{R} 2$ & $1.89 \mathrm{R} 1$ and $1.78 \mathrm{R} 2$ \\
\hline $21-50 \mathrm{~g}$ & $0.61 \mathrm{R} 1$ and $0.37 \mathrm{R} 2$ & 2.14 R1 and $2.26 \mathrm{R} 2$ & $21-50 \mathrm{~g}$ & $0.89 \mathrm{R} 1$ and $0.99 \mathrm{R} 2$ & $2.70 \mathrm{R} 1$ and $2.70 \mathrm{R} 2$ \\
\hline $51-80 \mathrm{~g}$ & $0.56 \mathrm{R} 1$ and $1.31 \mathrm{R} 2$ & $2.57 \mathrm{R} 1$ and $2.03 \mathrm{R} 2$ & $51-80 \mathrm{~g}$ & $0.58 \mathrm{R} 1$ and $0.71 \mathrm{R} 2$ & $1.76 \mathrm{R} 1$ and $1.66 \mathrm{R} 2$ \\
\hline \multicolumn{3}{|c|}{$\mathrm{pH} 8.5$} & \multicolumn{3}{|c|}{$\mathrm{pH} 9.0$} \\
\hline $10-20 \mathrm{~g}$ & $0.37 \mathrm{R} 1$ and $0.70 \mathrm{R} 2$ & $2.62 \mathrm{R} 1$ and $3.26 \mathrm{R} 2$ & $10-20 \mathrm{~g}$ & $0.37 \mathrm{R} 1$ and $0.15 \mathrm{R} 2$ & $2.11 \mathrm{R} 1$ and $1.52 \mathrm{R} 2$ \\
\hline $21-50 \mathrm{~g}$ & $0.26 \mathrm{R} 1$ and $0.20 \mathrm{R} 2$ & $2.96 \mathrm{R} 1$ and $1.88 \mathrm{R} 2$ & $21-50 \mathrm{~g}$ & $0.49 \mathrm{R} 1$ and $0.21 \mathrm{R} 2$ & $2.93 \mathrm{R} 1$ and $1.36 \mathrm{R} 2$ \\
\hline $51-80 \mathrm{~g}$ & $0.85 \mathrm{R} 1$ and $0.89 \mathrm{R} 2$ & 3.56 R1 and $2.88 \mathrm{R} 2$ & $51-80 \mathrm{~g}$ & 1.15 R1 and $1.91 \mathrm{R} 2$ & $2.41 \mathrm{R} 1$ and $2.16 \mathrm{R} 2$ \\
\hline
\end{tabular}

equilibrium at a certain $\mathrm{pH}$. At $\mathrm{pH} 7.5$ to 9.0, the ion speciation as written in Eq. 1-3 suggests that phosphate ions at $\mathrm{pH} 7.5-8.0$ are dominated by $\mathrm{H}_{2} \mathrm{PO}_{4}^{-}$and $\mathrm{HPO}_{4}{ }^{2-}$. At the increased $\mathrm{pH}$, i.e., $\mathrm{pH} 8.5$ to 9.0, the speciation of phosphate ions that acted in mobility is $\mathrm{HPO}_{4}{ }^{2-}$. The mobility of $\mathrm{H}_{2} \mathrm{PO}_{4}^{-}$and $\mathrm{HPO}_{4}{ }^{2-}$ is known to be $0.24 \times 10^{-7} \mathrm{~m}^{2} / \mathrm{s} /$ volt and for ionic mobility of fluoride ion of 0.57 x $10^{-7} \mathrm{~m}^{2} / \mathrm{s} /$ volt (Engelke \& Strain, 1954, Atkins $\&$ de Paula, 2006). Meanwhile, the mobility of phosphate at $\mathrm{pH} 9$ is similar to $\mathrm{pH} 10$ in the form of $\mathrm{PO}_{4}^{3-i o n}$ speciation, which reached its equilibrium at $\mathrm{pH}$ 10-12 (Canham \& Overton, 2010). $\mathrm{PO}_{4}{ }^{3-}$ ion speciation has higher mobility than the speciation of other ions of phosphate, i.e, $0.9 \mathrm{x}$ $10^{-7} \mathrm{~m}^{2} / \mathrm{s} /$ volt (Engelke \& Strain, 1954). Moreover, ammonium and calcium have the ability to migrate with ionic mobility of $0.76 \times 10^{-7} \mathrm{~m}^{2} / \mathrm{s} /$ volt and $0.61 \times 10^{-7} \mathrm{~m}^{2} / \mathrm{s} /$ volt (Vanysek, 2002). The ionic speciation based on $\mathrm{pH}$ condition can be noted as follows:

$$
\begin{aligned}
& \mathrm{PO}_{4}^{3-}{ }_{\text {(aq) }}^{3-}+\mathrm{H}_{2} \mathrm{O}_{(\mathrm{l})} \leftrightarrow \mathrm{HPO}_{4}^{2-}{ }_{(\text {aq })}+\mathrm{OH}_{(\text {aq) }}^{-} \\
& \mathrm{HPO}_{4}^{2-}{ }_{\text {(aq) }}+\mathrm{H}_{2} \mathrm{O}_{(\mathrm{l})} \leftrightarrow \mathrm{H}_{2} \mathrm{PO}_{4 \text { (aq) }}^{-}+\mathrm{OH}_{\text {(aq) }}^{-} \\
& \mathrm{H}_{2} \mathrm{PO}_{4(\mathrm{aq})}^{-}+\mathrm{H}_{2} \mathrm{O}_{(\mathrm{l})} \leftrightarrow \mathrm{H}_{3} \mathrm{PO}_{4(\mathrm{aq})}+\mathrm{OH}_{(\mathrm{aq})}^{-}
\end{aligned}
$$

\section{Struvite precipitation}

The struvite precipitation was performed based on the concentration and molar ratio from the mixed concentrate of Reactor 1 and 2. Prior to struvite chemical precipitation in a batch system, prediction of precipitate was simulated using
Phreeqc Interactive software. Table 3 describes the level of phosphate concentration, the molar ratio of phosphate:ammonium and the low concentration of ion impurities in the concentrated stream selected for the struvite precipitation process. The magnesium molar ratio was calculated by the selected concentrate so that the targeted precipitate to achieve was struvite. Following this, the Phreeqc simulation was conducted to estimate the required amount of magnesium and $\mathrm{pH}$.

The analysis results using phase identification of XRD at $\mathrm{pH} 8.5$ is presented in Table 4. The results show that the optimum removal percentage was achieved at the magnesium molar ratio of 2 for ammonium, whereas at the magnesium molar ratio of 2.5 for phosphate. In the study by Warmadewanthi \& Liu (2009), it was explained that higher magnesium molar ratios resulted in a small percentage of ammonium removal. In the simulation, when comparing the precipitates formed, a larger amount of struvite was formed at the molar ratio of 2.5:13:1 (magnesium:ammonium:phosphate), i.e., $57.3 \%$. However, other precipitates such as fluorapatite and $\mathrm{MgF}_{2}$ were also produced. Struvite and fluorapatite compositions in that molar ratio were determined by the difference of induction time.

According to Kabdasli et al. (2006), the induction time of struvite tends to be stable at 1580 minutes. The fluorapatite precipitate requires 40 minutes for the induction process (Deng et al., 2016). The induction time is one of the factors that may affect the increased formation of struvite rather than fluorapatite precipitates. The

Table 3. Concentration and molar ratio of total concentrate

\begin{tabular}{|c|c|c|c|c|c|c|c|c|}
\hline \multirow{2}{*}{ No } & \multicolumn{4}{|c|}{ Total concentrate $(\mathrm{mg} / \mathrm{L})$} & \multicolumn{4}{|c|}{ Total concentrate (molar ratio) } \\
\cline { 2 - 9 } & $\mathrm{PO}_{4}{ }^{3-}$ & $\mathrm{NH}_{4}{ }^{+}$ & $\mathrm{F}^{-}$ & $\mathrm{Ca}^{2+}$ & $\mathrm{PO}_{4}{ }^{-}$ & $\mathrm{NH}_{4}{ }^{+}$ & $\mathrm{F}^{-}$ & $\mathrm{Ca}^{2+}$ \\
\hline 1 & 813 & 1,934 & 70 & 20 & 1 & 13 & 0.4 & 0.06 \\
\hline 2 & 1,286 & 1,825 & 111 & 30 & 1 & 7 & 0.4 & 0.06 \\
\hline 3 & 731 & 1,410 & 53 & 27 & 1 & 10 & 0.4 & 0.09 \\
\hline
\end{tabular}


Table 4. The result of phase identification simulated at $\mathrm{pH} 8.5$

\begin{tabular}{|c|c|l|}
\hline No. & $\begin{array}{c}\text { Molar ratio } \\
{\left[\mathrm{Mg}^{2+}\right]:\left[\mathrm{NH}_{4}^{+}\right]:\left[\mathrm{PO}_{4}{ }^{3-}\right]}\end{array}$ & \multicolumn{1}{|c|}{ Precipitates formation } \\
\hline 1. & $2.5: 13: 1$ & $\begin{array}{l}\text { Struvite }(57.3 \%), \text { Fluorapatite } \\
(37.3 \%), \text { and } \mathrm{MgF}_{2}(5.4 \%)\end{array}$ \\
\hline 2. & $2: 7: 1$ & $\begin{array}{l}\text { Fluorapatite }(55.5 \%) \text { and } \\
\mathrm{MgNH}_{4}\left(\mathrm{PO}_{3}\right)_{3}(44.5 \%)\end{array}$ \\
\hline 3. & $2: 10: 1$ & $\begin{array}{l}\text { Struvite }(54.6 \%) \text { and } \\
\text { Fluorapatite }(45.4 \%),\end{array}$ \\
\hline
\end{tabular}

XRD results were supported by morphological results of crystals through SEM and EDX analysis (Figure $5 \mathrm{a}$ and $5 \mathrm{~b}$ ). On the basis of the crystals morphology produced in molar ratio 2.5:13:1 (magnesium:ammonium:phosphate), amorphous struvite crystal was observed. Figure 5a depicts irregular crystals, although it was previously mentioned by Rahman et al. (2011) and Kim et al. (2007) that struvite crystal is generally represented as regular crystal form. However, the formed struvite crystal can possibly be affected

a)

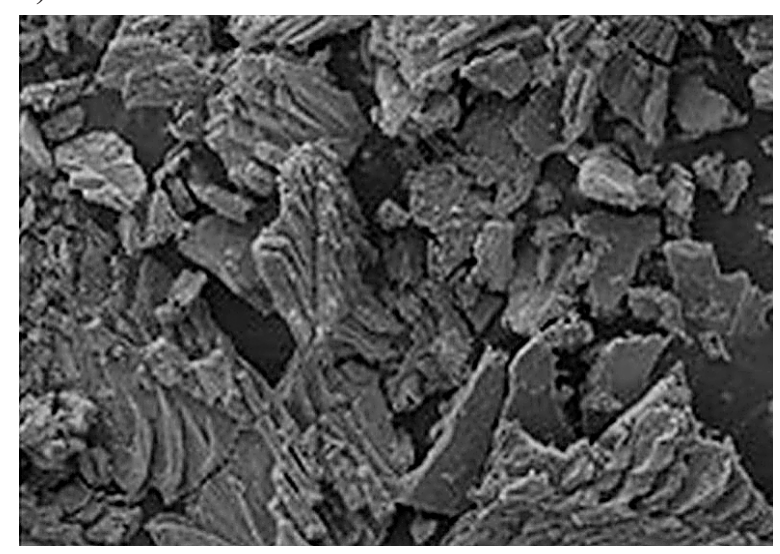

b)

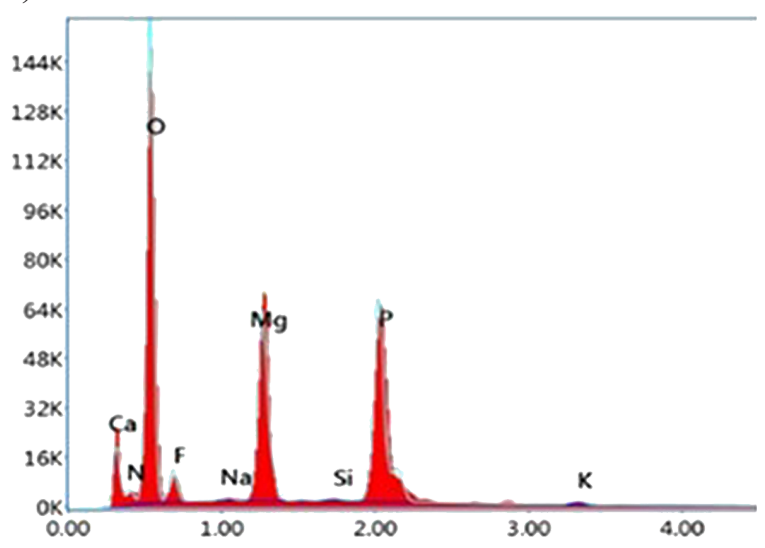

Figure 5. (a) Morphological analysis and

(b) EDX spectrum of struvite formed

in magnesium:ammonium:phosphate molar ratio of $2.5: 13: 1$ by calcium and fluoride ions. The EDX results confirmed that $\mathrm{Ca}$ and $\mathrm{F}$ elements were identified, besides $\mathrm{Mg}, \mathrm{N}, \mathrm{P}, \mathrm{O}$ elements (i.e., struvite constituents). Therefore, those impurity elements likely affect the struvite precipitation forms.

\section{CONCLUSIONS}

Electrodialysis was performed to obtain higher recovery of phosphate and ammonium as well as to remove the impurity ions contained in the fertilizer wastewater. The optimum removal was obtained at $\mathrm{pH} 7.5-8.5$, apparently due to the ionic mobility and speciation to transfer through the membrane. Moreover, initial phosphate mass loading in the wastewater influent affects the recovery rate. At $\mathrm{pH} 7.5$, the recovery process with phosphate mass loading of up to 51-80 g performed efficiently in Reactor 1 and 2, i.e., 0.44$0.56 \mathrm{~g}$ phosphate was obtained in Reactor 1 and $0.37-1.31 \mathrm{~g}$ in Reactor 2. Under the same conditions, up to $2.99 \mathrm{~g}$ and $2.26 \mathrm{~g}$ of ammonium were recovered in Reactor 1 and Reactor 2, respectively. The results suggest that the optimum concentrate stream consisted of $813 \mathrm{mg} / \mathrm{L}$ of phosphate and $1,934 \mathrm{mg} / \mathrm{L}$ of ammonium. This stream was then further treated to obtain struvite precipitation by adding magnesium with the magnesium:ammonium:phosphate molar ratio of 2.5:13:1. This ratio led to the production of 57.3 $\%$ struvite (by mass) with the other precipitate products, i.e., fluorapatite and $\mathrm{MgF}_{2}$.

\section{Acknowledgements}

The authors would like to acknowledge the Ministry of Research, Technology and the Higher Education of the Republic of Indonesia for supporting this study through the Research Grant Scheme 2018.

\section{REFERENCES}

1. Ali M.B., Mnif A., Hamrouni B., \& Dhahbi M. 2010. Electrodialytic desalination of brackishwater: effect of process parameters and water characteristics. Ionics, 16 (7), 621-629.

2. Atkins P., \& de Paula J. 2006. Physical chemistry. W. H. Freeman, New York.

3. Bagastyo A.Y., Anggrainy A.D., Nindita C.S., \& Warmadewanthi 2017. Electrodialytic removal of fluoride and calcium ions to recover phosphate 
from fertilizer industry wastewater. Sustainable Environmental Research, 27, 230-237.

4. Canham G.R., \& Overton T. 2010. Descriptive inorganic chemistry. W.H. Freeman and Co, New York.

5. Deng L., Liu Y., Huang T., \& Sun T. 2016. Fluoride removal by induced crystallization using fluorapatite/calcite seed crystals. Chemical Engineering Journal, 287, 83-91.

6. Engelke J.L., \& Strain H.H. 1954. Electrical mobility of phosphate ions in paper electrochromatography. Analytical Chemistry, 26 (1872), 4.

7. Kabdasli I., Parsons S.A., \& Tunay O. 2006. Effect of major ions on induction time of struvite precipitation. Croatica Chemica Acta, 79 (2), 243-251.

8. Karimi L. 2015. Theoretical, experimental, and predictive model for ion removal in electrodialysis and electrodialysis reversal. Ph.D. Thesis, New Mexico State University, Las Cruces.

9. Kim J.O., Jung J.T., \& Chung J.W. 2007. Treatment performance of metal membrane microfiltration and electrodialysis integrated system for wastewater reclamation. Desalination, 202, 343-350.

10. Momberg G., \& Oellermann R. 1992. The removal of phosphate by hydroxyapatite and struvite crystallisation in South Africa. Water Science and Technology, 26, 987-996.

11. Mondor M., Masse L., Ippersiel D., Lamarche F., \& Masse D. 2008. Use of electrodialysis and reverse osmosis for the recovery and concentration of ammonia from swine manure. Bioresource Technology, 99 (15), 7363-8.

12. Mulder M. 1996. Basic Principles of membrane technology, 2nd ed. Kluwer Academic Publisher, Dordrecht.

13. Novalin S., Kongbangkerd T., Reisinger M., \& Pruksasri S. 2017. Integration of electrodialysis into an enzymatic synthesis for the separation of phosphate from glucose-1-phosphate. Separation and Purification Technology, 182, 224-229.

14. Rahman M.M., Salleh M.A., Rashid U., Ahsan A., Hossain M.M., \& Ra C.S. 2011. Recovery of struvite from animal wastewater and its nutrient leaching loss in soil. Journal of Hazardous Material, 186, 2026-2030.

15. Rahman M.M., Liu Y.H., Kwag J.H., \& Ra C.S. 2014. Production of slow release crystal fertilizer from wastewater through struvite crystallization - A review. Arabian Journal of Chemical, 7, 139-155.

16. Strathmann H. 2004. Assessment of electrodialysis water desalination process costs, material discourse lectures. University of Stuttgart, Germany.

17. Vanysek P. 2002. Ionic conductivity and diffusion At infinite dilution. In: CRC Handbook of Chemistry and Physics, 83rd Edn; ed. D. R. Lide. CRC Press, Boca Raton.

18. Wang X., Wang Y., Zhang X., Feng H., Li C., \& Xu T. 2013. Phosphate recovery from excess sludge by conventional electrodialysis (CED) and electrodialysis with bipolar membranes (EDBM). Industrial \&Engineering Chemistry Research, 52(45), 15896-15904.

19. Wang X., Zhang X., Wang Y., Du Y., Feng H., \& $\mathrm{Xu}$ T. 2015. Simultaneous recovery of ammonium and phosphorus via the integration of electrodialysis with struvite reactor. Journal of Membrane Science, 490, 65-71.

20. Warmadewanthi \& Liu J.C. 2009. Recovery of phosphate and ammonium as struvite from semiconductor wastewater. Separation and Purification Technology, 64 (1-3), 368-373.

21. Zhang Y., Desmidt E., Van Looveren A., Pinoy L., Meesschaert B., \& Van der Bruggen B. 2013. Phosphate separation and recovery from wastewater by novel electrodialysis. Environmental Science \& Technology, 47 (11), 5888-5895. 